\title{
Mysticism in the Poetry of W. B. Yeats and Lal Shahbaz Qalander: A Comparative Study
}

\author{
Rehana Anwer ${ }^{1}$, Muhammad Arfan Lodhi' ${ }^{2, *}$, Sidra Anam ${ }^{3}$ \\ ${ }^{1}$ NCBA \& E University Lahore, Pakistan. \\ ${ }^{2}$ Higher Education Department (Collegiate Wing) Punjab, Pakistan. \\ ${ }^{3}$ NCBA \& E University Lahore, Pakistan.
}

\begin{abstract}
How to cite this paper: Rehana Anwer, Muhammad Arfan Lodhi, Sidra Anam. (2021). Mysticism in the Poetry of W. B. Yeats and Lal Shahbaz Qalander: A Comparative Study. The Educational Review, USA, 5(7), 213-225.

DOI: 10.26855/er.2021.07.005
\end{abstract}

Received: June 28, 2021

Accepted: July 20, 2021

Published: July 27, 2021

Corresponding author: Muhammad Arfan Lodhi, Higher Education Department (Collegiate Wing) Punjab, Pakistan.

Email: samaritan_as@hotmail.com

\begin{abstract}
The work addresses the mystical elements in the selected poems of W. B. Yeats and Lal Shabaz Qalander. For this purpose, the concept of mysticism and Sufism was understood in the light of different material taken from books, journals and articles. After thorough study of concerned literature, the selected poems were analyzed on the mystic pattern as suggested by Elvyn Underhill's book on the mystic consciousness. It was a qualitative study which revealed that mysticism is a universal temperament and mystics are special persons irrespective of any religion, time and space and share the same characteristics. The mystics do not use their intellect but depend on sixth sense which enables them to comprehend reality and truth. They believe in invisible powers and sharpen their senses to go beyond the visible and be immortal. They cross the limits of time and space; both mystics under observation share the qualities of mysticism and attain eternity in their poetry and work. Mysticism and spirituality are bent of mind and these tendencies can be developed by conscious efforts. Latest research on brain has proved that mind has been bestowed with excellent powers of contemplation. By developing an attitude of concentration and meditation one can easily achieve the status of a mystic if he is able to purify his soul.
\end{abstract}

\section{Keywords}

Mysticism, Sufism, dhammal, gyre, contemplation, spiritualism

\section{Introduction}

This research aims to explore mysticism, and the basic concept of Western and Islamic mysticism. It reveals quest for truth of a mystic, his endeavor to discover truth or ultimate Reality. It further tells about mystics strive for Immortality or eternity by uniting their soul after purgation with the Absolute Reality or God. In this regard selected poems of W. B. Yeats and Lal Shabaz Qalander have been studied to discover mystical elements. Their concept of truth immortality, eternity, timelessness, and symbolism has been studied from Western and Islamic concept of mysticism. Their concept of Time and Space, love for beauty, love for God and their desire for immortality has also been studied. This paper after analysis of mystical elements in the poetry of both poets has compared basic concepts of Western and Islamic mysticism and highlights cultural similarities and dissimilarities. Mystics are special persons who try to seek God through rapture and ecstasy. Nicholson (2002) states that there are three types of persons who devote their lives in hope to unite with God; they are worshippers, philosophers and Gnostics. 


\subsection{Background of the Study}

Mysticism is an old topic, yet it attracts the attention of readers and researchers even in this modern era of science and technology. It would be good to quote Elvyn Underhill (1912) at this moment whose book on mysticism is concerned about the nature and development of man's spiritual consciousness. Underhill (1912) defines mysticism as "the science of ultimate, the science of self-evident Reality, which cannot be reasoned about, because it is the object of pure reason or perception". The goal is purification of the soul. The purification of the soul is concerned with heart as Nicholson (2002) believes that for spiritual communication three organs are involved; the heart, the soul and the mind. On the same note, Jalal-u-Din Rumi, great mystic believes in the superiority of man to angels and fall of man than brutes if soul is not controlled. Tuluce (2017) in his thesis on Yeats "A neo-Platonic approach to his poetry" discusses about Yeats development as a mystic. Yeats remained under a mystic influence throughout his life and made conscious efforts to comprehend this concept of Truth and Reality. These ideas are further elaborated by Yang (2014) in his research on thematic study of time and art. Yang (ibid) discusses in his article how immortality can be achieved with the help of love, memory and art.

Yang (2015) in his thematic study of time analyzed the powerful effects of occultism, mythology and elaborates a mystical vision. On the other hand, when life and poetry of Qalander is observed mystic dance is used to achieve mystic reality. Mokhttar (2017) observes dhammal at the "Urs" (pilgrimage) of Qalander and explains how the body of a devotee becomes an expressive body and is symbolic of mysticism. In order to comprehend Qalander one must explore Islamic mysticism. Similarly, Amad (2013) explores the well of Islamic mysticism through history and studies its background and its position in the turmoil of contemporary world. There are two branches of knowledge which help a mystic on the path of elevation; the Elam and Marifa. Mysticism and reality can never be segregated and Malik (2013) proposes in his research article on mysticism that it is a surest short cut to achieve reality. Islamic and western mysticism has parallel strains irrespective of religion and in this regard Amazesh (n.d.) in his article "The teaching of a Sufi master” says Sufism preaches no dogma, except the great truths that are the basis of all religious beliefs. Asghari (2016) in the mystical interpretation of Islam explains that the term mystic refers to something that is hidden or concealed. Gerson (2010) says about the power of intellect which is a self-satisfying activity and helps a man to think beyond the limits of physical and bodily realm. Intellect cannot be bounded by essence, so it must be kept at rest. For mysticism one has to sharpen spiritual qualities.

\subsection{Rationale of the Study}

The following research will highlight the unique and interesting but difficult topic of mysticism. The stages to achieve mystical perfection will be explored both in the Eastern and Western literature. It explores how a person achieves enlightenment by purifying one's soul. Much of the work has been done on W. B. Yeats and his concept of mysticism. Yet the poetry of Lal Shabazz Qalander has not been studied by many especially foreigners. This study enables readers to discover mystical elements in his poetry and better comprehend Islamic well of mysticism.

\subsection{Research Questions}

1) What is mysticism and search for the difference between eastern and western mysticism keeping in mind the poetry of Lal Shabazz Qalander and W. B. Yeats?

2) What is W. B Yeats concept of mysticism and what mystical elements are found in his poetry?

3) What is Lal Shabazz Qalander concept of mysticism or what mystical elements are found in the poetry of Lal Shabazz Qalander?

4) What are modern man's issues of mental and spiritual deprivation and how these psychological problems can be tackled by understanding and practicing mysticism?

\section{Review of the related Literature}

\subsection{Sufism and Mysticism}

The word mystic has been derived from the Greek word muo which means to 'conceal' and in common parlance it means to access the transcendental being without reasoning or emotions. It is not a matter of intellect and a mystic first believes before knowing anything. Underhill (1912) wrote a valuable book on mysticism and describes the seven stages of a Mystic Way or how a mystic achieves transcendental stage by training his soul in a specific manner. Mystics are not ordinary people as Shah (2016) calls Sufis as extra ordinary people who are cut off from the Objective reality. He says that Sufi word is derived from ashabi-sufa, who was engaged in the period of Muhammad about theological issues. 
This concept is further elaborated by Bilques (2014) who defines mysticism as progress of a person or devotee from the first stage of Iman (Belief) to the final stage of Ihsan (Favor). James (2002) explores that mysticism is a part of sensation rather conceptual thought He believes in the power of intuition rather mere knowledge which is sometimes misleading.

\subsection{Branches of Mysticism}

Underhill (1912) further says mysticism has two branches, first the process of remaking his personality. It is called the mystic way in which self passes through different stages of development called as purgation and illumination of soul. Secondly, the mystical perception; how he was enabled to contemplate the reality. In this perspective, Kandi (2013) says mystical experience is always dealt with wonder and has been observed in all ages and in all religions of the world.

\subsection{Characteristics of Mysticism}

The first quality is that it is practical not theoretical. We can also say as revelation is personal, similarly the mysticism is personal. In the words of Imam Ghazali mystics depend on intuition not on words. Only knowledge and learning are not sufficient for it, but it requires true experience. Secondly, mysticism is transcendental it means that it is a purely spiritual activity and cannot be mixed with magic or any such belief. The Mystic way tells how a person or mystic develops a mystic consciousness and makes himself aloof from the normal human beings.

\section{(1) The Awakening of the Self}

The first stage is the awakening or conversion of the self; it is abounded by joy and excitement. Smith (1977) also narrates three stages of mystical experience and these are defined as purgative, illuminative and Unitative life. In the same vein, Farah (2003) says a mystic can unite with divine if he follows the path of Tariqa (Path) and it will help him in union with the Divine.

\section{(2) Purification of the Soul}

Brown (2004) narrates different stations and situations on the mystic way and tells us about the first station which is Mujahida or spiritual struggle or purification of the soul. This is a struggle of a Sufi against his habits and emotions. Hence Daniels (2003) says that the word mysticism has gone through many transformations. In modern world, it means a set of beliefs comprising paranormal, occultism, magic spiritualism and powerful experiences of the saints. But all the above activities of mysticism are attached with the purification of heart and soul.

(3) Illumination of the self

Third step on the mystic way is illumination of the self. It means the kind of perception different from the normal men. Brown (2004) considers the illumination of self as Tawakal (Reliance) or complete trust in God. The Sufi trusts in God and is content with God.

(4) Voices and Visions

The abnormal psychic phenomena are like a battlefield in the life of a mystic. These are auditions, dramatic dialogues, Soul, Love, Reason or the voice of God. These visions and voices are termed as hallucination by psychologists. Therefore, Azmayesh (n.d.) describes dreams as astral voyages. The astral body can catch the electromagnetic waves and travel on them. The astral body during dreaming helps to solve many mysteries. The astral body returns to physical body as the person wakes. The dreams of a mystic are very symbolic.

(5) Introversion: Recollection and Quiet

Contemplation is a powerful source of a mystic. Contemplation has same relation to a mystic as harmony is to music and color is to the artist. While discussing contemplation Azmayesh (n.d.) cannot be ignored who defines remembrance as an act of concentration on the names and qualities of the Divine for the training of the soul.

\subsection{Lal Shabaz Qalander as a Poet}

Qazi (1971) says that the biographical information about Lal Shabazz Qalander are not available in the form of books but different historical resources help a lot in gathering information about Lal Shabazz Qalander. He was born in Azerbaijan in a small town Marwand in Tabriz. He was named as Usman and popularly known as Marvandi due to association with Marwand. He was a great lover of travelling and journey; he visited Mecca and Medina and improved his spiritual education by linking with different prominent scholars of his time. In this regard, Mehar (2012) narrates that it was a command from his mentors to visit and permanently settle in Sehwan. It was a place immerged in the worst evils of time. Mohammad (1978) inquired about the title of Qalander and elaborates that there are three Qalander in the world; 
one Bu Ali Qalander of Panipat, Rabia Basri of Basra and Lal Shabazz Qalander of Shewan. He was called a Qalander because of extreme spiritual powers. Khan and Naqvi (2020) wrote about Lal Shabaz Qalander as the "Red Falcon" who was considered God, s beloved friend and no doubt is the soul of Sehwan. Sehwan is a small town in Sindh and situated $300 \mathrm{~km}$ away from Karachi. It is considered a holy place due to the presence of Lal Shabaz Qalander in this area. Therefore, the devotees wait anxiously for the annual Urs of the Qalander and Frembgen (2011) wrote extensively on the Urs of Lal Shabaz Qalander because he is doing research on the Sufi culture in Pakistan. Urs are source of cultural richness and traditional rites. Bovine (2012) concentrates on art and culture of the shrine and discussed shabaz' poetry full of sophist culture. Whereas, Frembgen (2011) focuses on the poster culture of the shrine, he studies these posters in socio-cultural context. Pakistani shrines and their culture are often studied by foreign scholars.

\subsection{W. B. Yeats as a Poet}

Watts (1994) says that W. B Yeats was born in Dublin on $13^{\text {th }}$ June 1865 . His father's name was John Butler Yeats (1839-1922). He was a lawyer and then shifted his career to a painter. The childhood of Yeats was spent in London and Ireland and he observed two extremes of urban and rural lives. In Ireland, he met with many relatives who enjoyed mystical revelations. William got his schooling from Godolphin school in Hammersmith then he joined Erasmus high school of Dublin. He also joined Metropolitan school of art in Dublin but soon left it and decided to start his career as a writer. Divya (2017) wrote in his article about the ups and downs of Yeats life. His poetic career was of thirty-five years. He observed many upheavals not only in his life but also in the world. He commented on all these events in a specific poetic way. Oza (2017) presents a comparative study of Yeats and Rabindranath Tagore, he considers both as the greatest poet of the twentieth century. Yeats was a great legend of the $20^{\text {th }}$ century who ventured for peace and order in the world. This search for order was linked with his life and Al-Douri (2020) wrote in his article about Yeats quest for order and the manifestation of this order in his work. Ross (2009) wrote in the biography of William that the life of the poet was many-faceted, but the most important aspect was his love for mystical life and living. Harper (2006) says that when Yeats was a young boy and man, the social world was facing the crisis of faith and convictions. Holdman (2006) further wrote in the "Cambridge Introduction to W. B. Yeats" England was always disliked by Yeats for he associates it with imperialism, materialism and a God less progress. Divya (2017) talks about the identity and various themes of Yeats in his article" Various themes and their treatment in W. B. Yeats”. He says that the issue of Yeats identity was first raised by Richard Ellaman in his book the Identity of Yeats, Yeats was considered as a nationalist, colonialist, anti-colonialist and revolutionary poet. Ross (2009) explains how Yeats was inspired by the Romantics; his father used to recite the Prometheus Unbound in a loud voice. Khan (2015) wrote in his article about the theological and philosophical system of Yeats, although he rejected Christianity yet his whole life is a search in mythology, spiritualism, philosophy and occult. Rajashekara and Venkateshwara (2020) recognized Yeats as a great modern poet. Yeats is no doubt the finest of the British poets of the modern age.

\section{Methodological Framework}

\subsection{Research Framework}

Leedey and Ormrod (2001) explained that research methodology is a systematic way of data collection. Interpretation and analysis to achieve reliable results can be replicated easily. The framework of analysis provides a scheme to explain the objectives of the research and manage the data by communicating the findings. The exploratory framework has been adopted. Creswell (1994) explains that qualitative research leads the researcher towards some discovery or innovative ideas. The collected poems of W. B. Yeats, Wordsworth poetry library published in 1994 by Wordsworth edition limited 2008 and Sharah-e-Dewaan Lal Shabaz Qalandar was the population of the study (see Table 1).

Table 1. Population Framework

\begin{tabular}{cccc}
\hline Name of the book & Author & Publication Year & Publisher \\
\hline $\begin{array}{c}\text { The collected poems of W. B. Yeats, } \\
\text { Wordsworth poetry library }\end{array}$ & $\begin{array}{c}\text { Words Worth and W.B } \\
\text { Yeats }\end{array}$ & 2008 & Words Worth Publications \\
Sharah-e-Dewaan Lal Shabaz Qalandar & M. Ali Chiragh & 1998 & Nazir Sons Publishers \\
\hline
\end{tabular}

Selected poems of W. B. Yeats with clear content of mysticism and lyrics of Lal Shabazz Qalander with mystical elements were the sample of the study (See Table 2). 08 poems were selected randomly of each poet to undergo con- 
spicuous analysis of the poetical lines.

Table 2. Sample of the study

Text 1

The sailing to Byzantium

Among the School Children

The Tower

Tom the Lunatic

Crazy Janes

The Gyres

A Dialogue of self and soul

The sailing to Byzantium

Text 2

$$
\begin{aligned}
& \text { عثقان ا ندر جمال خو اب رويان مانده-غزل } \\
& \text { كر توبخو ابى دلا تا شاه با شى دائما غزل جل } \\
& \text { دردو عالم عشقان را جز خدا مقصود نيست غزل † } \\
& \text { جانما از سر كزشت عشق او بر سر كر فت غزله } \\
& \text { كر تجلى دوست خوابى بر دوام غزلV } \\
& \text { وجود محض مطلق را بمه جا بر زمان ديدم غزلى } \\
& \text { شهباز لا ماكانم بيرون ز كون و مكانم غزلها } \\
& \text { عشقان ا ندر جمال خو اب رويان مانده-غزل }
\end{aligned}
$$

Instrumentation means how data was collected and tools were applied to interpret and understand data to get the desired results. Primary and secondary data sources are used. For example, books, research articles, journals, newspapers and internet sources are widely used. The research tools include observation which enabled the researcher to arrive at a certain conclusion. The procedure was quite simple. First, the sample is analyzed thoroughly; then mystic way and its postulates have been studied individually. For analysis purposes, the content analysis is done, and the framework of analysis is described above. It has been adopted by the researcher on the whole text of the both poet. The data are identified, analyzed and then classified. After thorough analyzing selected poems of the both poets the results are logically interpreted. The selected poems are studied from the perspective of mysticism.

\subsection{Framework of Analysis}

The framework of analysis for the present study was developed from different perspectives of the concept of timelessness, immortality, self acknowledgement and self-actualization (Figure 1).

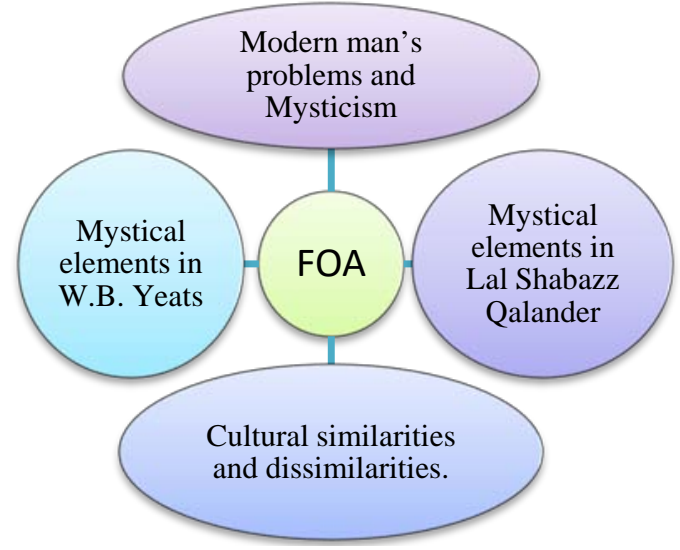

Figure 1. Framework of Analysis.

\section{Analysis and Discussions}

\subsection{Mystical Elements in W. B. Yeats}

Yeats is considered as one of the greatest and representative Irish poet. He is widely read poets of the $20^{\text {th }}$ century; Yeats was engrossed in the beauty, civilization and culture of Ireland. His work is abundant with timeless themes of human life; Love, beauty, life and death, immorality and man's existence in this transitory world (see Table 3).

\section{Awakening of the Self}

If Underhill's book on mysticism is studied, it will be easy to conclude that there are seven stages which a mystic must cover on his path of elevation. The first and foremost stage is the awakening of the self and during analysis it is 
quite clear that both the poets passed through this stage of awakening. Yeats in his poem Tower says in these words about the awakening of the self.

What shall I do with this absurdity-?

O' heart, Troubled heart-this caricature,

Decrepit get that has been tied to me

Imagination, nor an ear and eye

Table 3. Mystical Elements in W. B. Yeats

\begin{tabular}{|c|c|c|}
\hline No & Poem & Textual Reference \\
\hline 1 & Byzantium & $\begin{array}{l}\text { I hail the superhuman; } \\
\text { I call it death in life and life- in-death. }\end{array}$ \\
\hline 2 & Byzantium & $\begin{array}{l}\text { Where blood-begotten spirits come } \\
\text { And all complexities of fury leave }\end{array}$ \\
\hline 3 & Sailing to Byzantium & $\begin{array}{l}\text { Caught in that sensual music all neglect } \\
\text { Monuments of unageing intellect }\end{array}$ \\
\hline 4 & Sailing to Byzantium & $\begin{array}{l}\text { And be the singing masters of my soul. } \\
\text { Consume my heart away; sick with desire }\end{array}$ \\
\hline 5 & Among School Children & $\begin{array}{l}\text { O body swayed to music, Brightening glance, } \\
\text { How can we know the dancer from the dance }\end{array}$ \\
\hline 6 & Among School Children & $\begin{array}{l}\text { Labor is blossoming or dancing where } \\
\text { The body is not bruised to pleasure soul }\end{array}$ \\
\hline 7 & A Dialogue of Self and Soul & $\begin{array}{l}\text { That quarter-where all thought is done } \\
\text { Who can distinguish darkness from the soul }\end{array}$ \\
\hline 8 & A dialogue of self and soul & $\begin{array}{l}\text { Think of ancestral night that can } \\
\text { Deliver from the crime of death and birth }\end{array}$ \\
\hline 9 & A dialogue of self and soul & $\begin{array}{l}\text { For intellect no longer knows } \\
\text { Is from the ought, or knower from the known } \\
\text { Ascends to heaven }\end{array}$ \\
\hline
\end{tabular}

\section{Purification of the Soul}

Purification of soul is the next step on the Mystic way. Purification and purgation are the mandatory steps on the mystic way. Yeats also believes in the purgation of the soul. In sailing to Byzantium, the theme of purgation has been narrated very artistically.

Come from the holy fire, perne in a gyre,

And be the singing masters of my soul,

Consume my heart away; sick with desire

\section{Illumination of the self}

Illumination of the self is inevitable if a mystic purifies his soul and this is a very important step in the further progress of spiritualism. As far as the illumination of the self is concerned the best poem is A Dialogue of Self and Soul, he himself called this cycle of dialogue as the crime of death and birth for which only the dead can be forgiven. Yeats believes that this is an impure world of accident and contingency, where generation is equal to death and then comes the spiritual death. It can be interpreted that death of body is the birth of soul or soul never dies if it is trained in a mystic way and a mystic can enjoy an eternal life. For example, in the Tower he has expressed his views in this way,

All those things whereof

Man makes a superhuman

Mirror-resembling dream 


\section{Voices and Visions}

The voices and Visions are the psychic phenomena which are experienced by almost all mystics. Experts Say that this stage is due to extreme imaginative power or hallucination. In a Dialogue of self and soul, the poet has a vision and he hears the voice of his soul.

Astraddle on the dolphins mire and blood, Spirit after spirit, the smithies breaks the flood.

The golden smithies of the emperor

\section{Introversion; Contemplation}

Contemplative argumentation reveals that a mystic develops a special quality which is dormant in common man. As mystic awakens in himself such a spark of soul which has an innate capacity to comprehend the Absolute. The mystic delivers himself from the self-centered life and awakens himself into a new universe and must observe the life process which develops a harmony between the self and reality. Contemplation to mystic is same as harmony to music, measure to poetry and color to artists.

The best lack all conviction, while the worst

Are full of passionate intensity

\section{Recollection and Quiet}

Recollection and quiet are first steps to reach the contemplation. The mystic starts his inward path by educating himself, it will be a break from the consciousness and departure from the obvious world. The first steps of contemplative life are very harsh and strenuous. In Among School Children, the poet recollects his love with Maud Gonne. The recollection and quiet leads man towards mysticism:

I dream of a Leaden body, bent

Above a sinking fire, a tale that she

Told of harsh reproof, or trivial event

\section{Ecstasy and Rapture}

The end of contemplation, recollection and quiet is that state of mind in which the mystic feels himself in union with transcendental and he declares that self is in God and God is in her. It is a consciousness which enables him to feel the Absolute. The ecstasy is the most exalted form of the spiritual consciousness.

Labor is blossoming or dancing where

The body is not bruised to pleasure soul.

How can we know the dancer from the dance?

\section{Dark Night of the Soul}

Mystics are not only artists but also, they are human beings endowed with all human facilities'. Through introversion they enjoy contemplation, ecstasy and rapture and at last enter in the dark night of the soul. The soul is matured and trained to reject the worldly pursuits and enjoy timelessness and immortality. In this period the mystic is at once lost and feels impotence, blankness and solitude. It knows not what it is; and gathers me
into the artifice of eternity

\section{Unitative Life}

A normal man has little awareness about his personality and a mystic has gone through the difficult process of remaking. Mystic finally achieved the peak of his rigorous journey in the form of union with God. There are laws of earth similarly there are laws of soul. When a man grasps full consciousness of reality; he completes the circle of being. A 
mystic becomes highly intuitive and strongly practical person.

\section{Now shall I make my soul, Compelling it to study \\ In a learned school}

\subsection{Mystical Elements in Lal Shabaz Qalandar}

Muhammad Osman Marwandi, popularly known as Lal Shabaz Qalander, was a Sufi saint who travelled to Sind, Pakistan. He made Shewan his place of abode and died here at the age of 112 in 1274 A.D. He is known as most famous saint of the poor. Qalander means a person among the group of mystics in the eastern lands of Islam who distinguished themselves by their unusual way of living.

\section{Table 4. Mystical Elements in Lal Shabaz Qalander}

\begin{tabular}{|c|c|c|}
\hline No & Poem & Textual Reference \\
\hline 1 & غزل نمبر 3 & 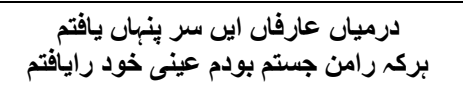 \\
\hline 2 & غزل نمبر3 & 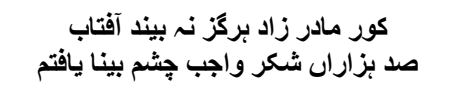 \\
\hline 3 & غزل نمبر4 & در شبود جُشم ايشان ريز دلى خلى مشبود نيست نيست \\
\hline 4 & غزال نمبر4 & 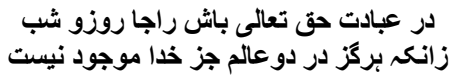 \\
\hline 5 & غزل نمبر6 & 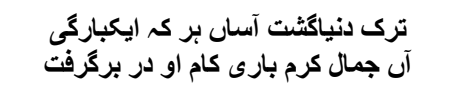 \\
\hline 6 & غزل نمبر7 & خؤ ترلي دوست بر خوابى بر دوام \\
\hline 7 & غزل نمبر8 & 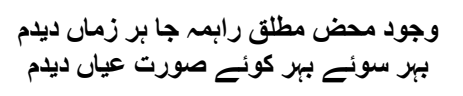 \\
\hline 8 & غزل نمبر15 & شسبجود لانس و جانم بيرون مطب كون و و مثيانم \\
\hline 9 & غزل نمبر16 & 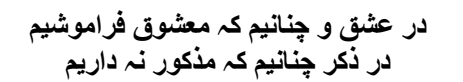 \\
\hline
\end{tabular}

Data were shown in Table 4 mentions selected poems of Lal Shabaz Qalander and dominant themes discussed in them. The main tenant of his poetry is love with Divine, it can be seen in the following poem. (351)

$$
\begin{aligned}
& \text { زعشق دوست بر ساعت دودى نارمى رقصم }
\end{aligned}
$$

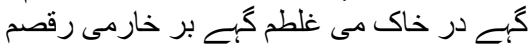

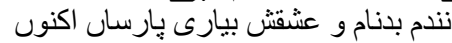

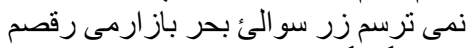

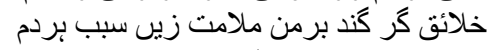

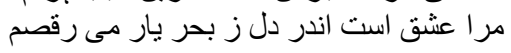

$$
\text { (غزل نمبر29 شرح ديوان) }
$$

Everyone is aware with the dervishes who dance and elevate their soul. There are different concepts about Islamic mysticism; some consider it as another religion. But it should not be confused with another religion or a sect. In fact Sufism is quite Islamic and soul and spirit of Islamic teaching. The basic teachings of Sufism are:

1. Strong belief in the presence of divinity

2. $\quad$ Strong belief in the presence of an invisible world

3. Strong belief in the immortality of the soul 


\section{Adherence to Sharia and Tariqa}

As in western mysticism, it has been observed that awakening of self is necessary for the journey of mysticism. In Islamic mysticism, the most important element is following the path of Sharia. Sharia enables a man to venture into the fathomless ocean of Sufism.

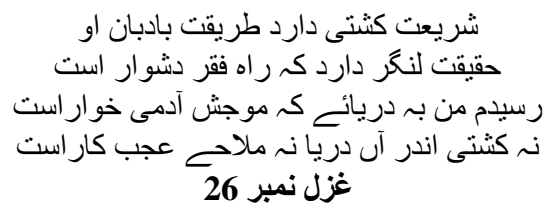

\section{Purification of Soul}

Purification of the soul or Tazkia nafas is a very difficult stage in which one has to say good bye to all the pleasures of the soul. World is full of colors and luxuries and it is very difficult to ignore this path of comfort and pleasure. The materialistic pursuits are captivating and make man forgetful of all spiritual realities. The purification needs total reluctance to this myopic world. In another poem, the poet in the following words talks about the purification of the soul.

$$
\begin{aligned}
& \text { غزل نمبر20 } \\
& \text { جون طمع بريدم و از خويش كزشتيم }
\end{aligned}
$$

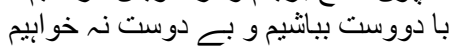

The poet says that he has freed himself from the shackles and bonds of egotism. Egotism is source and root of all evils and ills in the world. Vanity and pride also leads a man towards destruction and devastation. So, at this stage, he has freed his soul and his soul is enabling him to visualize the wonders of invisible world.

\section{Remembrance of God}

The western mystics complete their spiritual journey by passing through introversion. Introversion occurs in the form of recollection and quiet. The same stage in Islamic Sufism is Zikar. Yogi also does the mantra to achieve spiritual satisfaction. There are many verses in the poetry of Qalander which tell us that the poet is all the time engaged in the love and remembrance of God.

$$
\text { رفيقم برآن دوست ذكر بيج نكردم دوست دَّيدم }
$$

\section{Trust in God}

Tawakal or trust in God is the most important stage in the development of spiritual consciousness, without it the mystic cannot achieve the zenix of spiritual development. It is complete trust in God which enables the mystic to ignore all the charms spread around him. In the following lines he narrates about Trust in God. The trust in God is basic tenant of Sufi culture. A Sufi must not be mistrusted or doubtful about the benevolence and kindness of God.

$$
\begin{aligned}
& \text { كر تو بخو ابى الـ دلا تا شاه باشى دائما }
\end{aligned}
$$

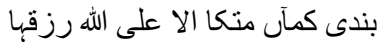

Love

Love is an important ingredient in the life and development of the soul. Love is a very purified passion and it is one of the most important attribute of Almighty Allaha. Love has power of magic. It can penetrate the hardness of a rock and can convert it into a spring. The Sufis all over the world used love to attract people towards their faith and love is such a passion which cannot be confined to races or languages.

$$
\begin{aligned}
& \text { درود عالم عاثقان راجز خدا مقصود نيست }
\end{aligned}
$$

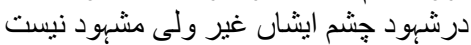

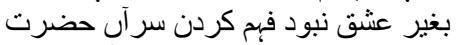

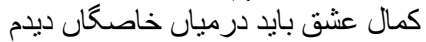

Voices and Visions

A Sufi on his path of mysticism experiences certain unusual things which may be considered by a common man as hallucination or psychological disturbances. But a Sufi feels these voices and visions on his journey of spiritual eleva- 
tion. His vision is very powerful, and he can visualize the wonders of invisible world. He has trained and educated his soul to that extent that the invisible world is now revealed to him.

\section{Contemplation}

Contemplation means reflection or profound thought on any one aspect of the Divine. It also means formation of mental image and under the training of master the repetition of certain words or phrase able to transform the devotee in the world of Reality. In the holy Quran, it is emphasized to observe and concentrate on the wonders of Nature. By through reflection and meditation one can perceive the Divine.

$$
\text { خور تجلى دوست خو ابى بر دوام }
$$

\section{Ecstasy or Rapture}

Ecstasy or rapture is important ingredients of mysticism. In Islamic mysticism, dhammal is very common among Sufis. In Turkey on the shrine of Maulana Rome, the dervish performs a typical dhammal or raqs to show the spiritual depth of the devotee. At the shrine of Sufi Lal Shabaz Qalander, the ecstatic dance shows sacred bodies merged in the love of their Murshid. The same thought is expressed in the following verse.

$$
\begin{aligned}
& \text { عاثقان را ذره نورش جوب آمد درنظر } \\
& \text { عانقق سرمست راديو انخى از سركرفت آدرنت }
\end{aligned}
$$

\section{Dark night of Soul (Fana)}

Dark night of soul (Fana) is the second last stage in the journey of a mystic. The poet has left all the pleasures of life. It was not easy to depart from the luxuries of life, but the love of god makes it easy for me. People are so engaged in these charms and lights that they forget the real purpose of their life.

$$
\text { ترك دنيا كثتت آسان بر كم ايكباركى }
$$

Unitative of Soul (Baqa)

In western mysticism, the Unitative life is the end of a mystic's life. If we compare it with Islamic mysticism, then Baqa is the goal of a Sufi. Qalander was a true Sufi and throughout his poetry desires for immortality and timelessness. The mystic wants to enjoy eternity of life. The same thoughts are expressed in the following lines,

$$
\begin{aligned}
& \text { اكر بوئَه خودى ماند بزار إن برده بابانثد } \\
& \text { فناديدم بقا بالله ميان عار فان ديدم }
\end{aligned}
$$

\section{Justifications of the Research Questions}

\subsection{What is Mysticism and search for the difference between Eastern and Western Mysticism keeping in mind the poetry of Lal Shabaz Qalander and W. B. Yeats?}

The study elucidated the meaning of Mysticism and Sufism separately. Common people call it a science of ultimate's or a Reality which cannot be perceived by senses or reason because it is a matter of pure reason or perception. Underhill (1912) concludes in his chapter on mysticism that it is not limited to sense impressions or intellection. Mystics do not believe in logic but life. They have a strong conviction that spirit of man is divine and can easily develop immediate communion with God. Tuluce (2017) defines mysticism as a state which cannot be acquired through rationality or sentiments. The word mysticism is derived from the Greek word "muo" which means to conceal. Schimmel (1992) advocates authors who wrote the ideology of Sufism in particular context of mystic poetry. In this regard, the work of Ghazali is prominent who narrated how he finally got solace in Mysticism.

\subsection{What is W. B. Yeats concept of Mysticism and what Mystical elements are found in his poetry?}

Yeats is mostly inspired by Plotinus and his philosophy ‘A Vision' written by Yeats is a slight modification of Plotinus philosophy. Yeats was inspired by the Plotinus Enneads and then he readjusted his Vision. He explains the Plotinus system in this manner Yang (2015) in his thematic study of time analyzed the powerful effects of occultism and mythology and elaborates a mystical vision. In his poems he introduced the concept of gyre which was symbolic of the rise and fall of civilizations. These interlocking gyres were representing time. In "Sailing to Byzantium", the importance of 
memory and recollection has been emphasized.

The poet describes binary of old age and gives preference to philosophy. He focuses on the purification of heart and can achieve unity through the art and artifice. In 'Tower', Yeats himself is the speaker and he is facing the dilemma whether to take refuge in philosophy or in art. He believes in the strength of art and philosophy. He failed to achieve the stage of 'Being' in terms of Plotinus but touches the boundary of eternity on his own terms and condition. His journey to Byzantium is symbolic journey of soul to seek the ultimate truth. The next poem which presents the mystical elements is 'A Dialogue of Self and Soul'. The dark night of soul which is an important ingredient of Mystic way according to Underhill has been discussed here. The writer discusses the depths of his soul and the limits of his self. The dialogues are a source of inspiration when a mystic is on the way of Spiritualism.

\subsection{What is Lal Shabaz Qalander concept of Mysticism or what Mystical elements are found in the poetry of Lal Shabaz Qalander?}

Amad (2013) explores the well of Islamic mysticism through history and studies its background and its position in the turmoil of contemporary world. The main tenant of his poetry is love he says that he is fully engrossed in the love of his beloved. The symbol of dance or dhammal is used which is stage of ecstasy and rapture and jazb and wajad in Islamic parlance. The poet in this lyric unfolds before us the deep and unfathomable world of Mysticism. The poet talks about Shariat and Tariqat which are the important ingredients of Sufism. The poet says to reach Truth one must plunge in the deep well of Divinity. He says that I plunged into such a river whose waves engulf man, there is no boat, no sailor in the river, no helper it is astonishing. To reach ‘truth' one must take plunge in this vast and wide ocean of Divinity which has no guide.

In Gazal no 17 Chiragh (1998), the poet says God you are beyond my comprehension one can access the unlimited 'Being'. The intellect here fails to grasp the reality of God. The Hadith of the Prophet (PBUH) would be a guideline for us that contemplate over the creations of God but never try to contemplate the creator. Contemplation or Fikar in Sufi vocabulary according to Azmayesh (n.d.) is practice for making mental images. It is meditation or reflection on the wonders of the Divine. The poet says he has lost his life and identity. I want to be recognized by the name of Almighty Allaha. I'm nothing without God, I have ended myself and pride. I was a drop and now I have lost my identity with the great ocean. The poet has achieved the timelessness. Gazal no 16 (ibid) is about the purification of self which is inevitable to enter in the pure and divine world of mysticism. He says I controlled myself and succeeded in vanishing my greed and lust. In mystic dictionary the purification of self is very important. The poet has been able to purge his soul from the all blemishes and blunders. After crossing this boundary of greed, the poet has entered a wonderful world of surprise and awe. For him the target of all desires is God. He has no other friend and his friend is the supreme of all. Shah (2016) recounts the seven stages of Hal or Maqam namely ecstasy or rapture in these words;

“(1) Repentance, (2) Abstinence, (3) Renunciation, (4) Poverty (5) Patience (6) Trusts in God, (7) Satisfaction”, and there are ten psychic state; "meditation, Nearness to God, Love, Fear, Hope, Longing, Intimacy, Tranquility, Contemplation and Certainty"

\subsection{What are modern man, $\mathrm{s}$ issues of mental and spiritual deprivation and how these psychological problems can be tackled by understanding and practicing Mysticism?}

The modern man's problems are no doubt the remoteness from God, spiritual barrenness, depression and stress. Sense of aimlessness, lust and infatuation, materialistic bent of mind leads a man towards destruction and devastation. Modern man is a hollow man as narrated by T. S. Eliot. He has no shape or form and is like a paralyzed force. W. B. Yeats also talks about the deprivation of modern man. Schmidle (2009) explains how dance and dhammal at the urs of Sufi Saint become a source of spirituality and purification of soul for men and women of all ages. Bruinessen, Howell (2007) comments on the role of mysticism in modern age, he comments that globalization, industrialization, economic growth and even Urbanization has not reduced the importance and significance of mysticism in Indonesia.

\section{Conclusion}

To conclude, Yeats and Lal Shabaz Qalander are not poets of excellence but Mystics of high caliber. They have succeeded in crossing the boundaries of temporal to transcendental. Both were trying to cross the binaries of age and youth; life and death; body and soul and lastly art and philosophy; the endeavor to awaken their souls in their own perspective. When the soul is fully conscious and awaken to receive the radiations from the transcendental world, they pass their souls to the purification and purgation processes. Many poetical lines evidently reflect about purification or Tazkia Nafs without which the soul remained entangled in the pleasures of this world. So far as Yeats is concerned he employs Plo- 
tinus ideas for example the emanation principle and different hypostases. In "Among School Children”, the memory and recollection principle are used to achieve the state of being. In "Sailing to Byzantium", the historical city of Byzantium is used to achieve timelessness and immortality. In 'Tower', he unites all binaries together, body and soul; earthly and divine love; art and philosophy to achieve a stage of mystical union. In Byzantium poem, he talks about purification of the soul. In the 'Dialogue of self and soul', he talks about the training of soul by intellect and imagination. He stops his soul to wander in the world of philosophy rather enjoy Mysticism.

On the other hand, Lal Shabaz Qalander proves himself to be a true mystic. He in different verses expresses his views about the awakening of the soul and then its purification. He narrates that vanity and pride are great hurdles in achieving immortality. He succeeds in liberating his soul from the bonds and shackles of this temporary world. He is not considering the time and space as an obstacle on his Mystic way. He talks about his Mystic vision which enables him to see the invisible world. It seems he has achieved Mystical union. He can even fly in this world with the power of his soul. Qalander has beautifully crossed the border of real and transcendental world. His stage of Baqa has been narrated by him. The most important conclusion of this research is that both poets fulfill all the demands of a mystic if judged on the model of Elvyn Underlies book on Mysticism.

\section{References}

Ai-Douri, H. H. (2020). W. B. Yeats and the Quest for Order. Koya University Journal of Humanities and Social Sciences, 3(1).

Amad, H. (2013). The Practice of Mysticism in Sufism, religion, culture and society. The Uclan Journal of Undergraduate Research, $6(1)$.

Asghari, S. A. (2016). Mystical Interpretation of the Quran. Burhar Journal of Quranic Studies.

Azmayesh, S. M. (n.d.). The teachings of a Sufi Master, Simorgh Sufi Society.

Bilques, S. (2014). Understanding the Concept of Islamic Sufism. Journal of Education and Social Policy, 1(1).

Boivin, M. (2012). Artefacts of Devotion: A Sufi Repertoire the Qalandariyya in Sehwan Sharif, Sindh, Pakistan. Karachi: Oxford University Press.

Brown, D. (2004). A New Introduction to Islam. Malden, MA: Blackwell publishing.

Bruinessen. (2007). Sufism and the Modern Islam. I.B. Tauris \& co, Ltd, London Company.

Creswell. (2013). Research Design: A Qualitative and Quantitative and Mixed Method Approach (2 ${ }^{\text {nd }}$ Ed). Thousands Oaks, A Sage Publication.

Daniels, M. (2003). “Making sense of mysticism.” Transpersonal Psychology Review, 7(1).

Divya. (2017). Various Themes and Their Treatment in W. B. Yeats Poetry. International Journal of Research and Development, 2(5).

Farah. (2003). Ceasar E. Islam. ${ }^{\text {th }}$ ed. Hauppauge, NY: Brrons Educational Series Inc.

Frembgen, J. W. (2011a). At the shrine of the red Sufi; Five days and nights on pilgrimage in Pakistan (J. Ripken, Trans.).

Frembgen, J. W. (2011b). The Friends of God- Sufi Saints in Islam: Popular Poster Art from Pakistan. Karachi: Oxford University Press.

Gerson, L. P. (2010). Plotinus. The Argument of the Philosophers. Taylor \& Francis eLibrary.

Harper, G. M. and Walter, K. H. (1978). Introduction to a critical edition of Yeats's a vision. London: The Macmillan Press LTD.

Harper, M. M. (2006). Yeats and the Occult. The Cambridge Companion to W. B. Yeats. Cambridge UP, pp. $144-167$.

Holdeman, D. (2006). The Cambridge Introduction to W. B. Yeats. Cambridge UP, In Embodying Charisma: Modernity, Locality and the Performance of Emotion in Sufi Cults. London \& New

James, W. (2002). The Varieties of Religious Experience: A Study in Human Nature. Routledge.

Kandi, S. (2013). Characteristics of Mystical Experience and Impact of Meditation. International Journal of Social Sciences, 2(2), December, 141-146, DOI:105958/2321-5771.2.2.007, Karachi: Oxford University Press.

Khan, A. H and Naqvi, A. I. (2020). Filming Shabaz Qalander: From Spectacle to Meaning, Dastavesi. The Audio-Visual South Asia, $1(2)$.

Khan, M. E. I. (2015). Theological evenness in W.B. Yeats; A Preamble. IJMRME, 1(1).

Leedey, P. D. and Ormrod. (2015). Practical Research, Planning and Design (11 ${ }^{\text {th }}$ ed.). Boston, Pearson, (2018), 2, 1(2), $23-44$. https://doi.org/10-37074/jalt.2018.1.2.15.

Mahar, R. D. (2012). Hazrat Lal Shabaz Qalander and his Poetry. IN A.K. Suhag A. Sagar (eds.), Qalanderam Mastam. Jamshoro, 
Pakistan: Shabaz Yadgar Committee.

Malik, A. (2013). Mysticism—A Parallel Religion. Al-Hikmat, 33 (2013), pp. 13-24.

Mohammad, I. (1978). Hazrat Lal Shahbaz Qalandar of Sehwan-Sharif. Karachi: Royal Book Company.

Mokhtar, S. (2012). Sacred Spaces and Expressive Bodies: At the Urs of Lal Shahbaz Qalander. School of Journalism and Communication.

Mohammad and Hassam. (2017). Occultism in Yeats, The Second Coming: A Critical Interpretation. IRSS, 5(2).

Nicholson, R. (2002). The mystics of Islam.

Oza, P. (n.d.). Modern Mystic Poet: Rabindranath Tagore Eternal/W. B. Yeats Ethereal.

Qazi, N. B. G. (1971). Lal Shahbaz Qalandar 'Uthman Marwandi. Lahore, Pakistan: R.C.D. Cultural Institute.

Rajashekara and Venkateshwara. (2020). W. B. Yeats Views on Poetry. Aegaeum Journal, 8(6).

Ross, D. A. (2009). Critical companion to reference: W.B.Y. A literary Reference to his life and work. InfoBase publishing.

Schimmel, A. (1992). Islam: An Introduction. Albany: State University of New York Press.

Schmidle, N. (2009). To live or perish forever; two Tumultuous years in Pakistan. New York: Henry Holt and Company.

Shah, I. (2016). The world of the Sufi, ISF PUBLISHING.

Smith, James L. Jr. (2005). “Sufism: Islamic Mysticism.” Verbum: 3(1) Article 10. Available at: https://fisherpub.sjfc.edu/verbum/ vol3/iss1/10.

Tuluce, M. (1917). William Butler Yeats and Mysticism: “A Neo-Platonic Approach to his poetry.”

Underhill, E. (1912). “Mysticism”, “A study in the Nature and Development of Man’s spiritual consciousness.” New York E, A Dutton and company.

Yang, S. (2014). The Thematic Study of time in Yeats Mystical Man. English Lit \& Long Studies, 4(4), 2014.

Yang, S. (2015). The Thematic Study of time in Yeats Mystical System. Advances in Literary Study, 31(6).

Watts. (1994). The collected Poems of W. B. Yeats, Wordsworth Poetry library. 